\title{
Understanding the Performance of the Banking System in Times of Crisis: the Case of Commercial Banks in the CEMAC
}

\author{
William Geslin Ondaye ${ }^{1}$ \\ ${ }^{1}$ Laboratory of Economic and Social Research and Studies, Faculty of Economic Sciences, Marien Ngouabi University, \\ Brazzaville, The Republic of the Congo \\ Correspondence: William Geslin Ondaye, Laboratory of Economic and Social Research and Studies, Faculty of \\ Economic Sciences, Marien Ngouabi University, Brazzaville, The Republic of the Congo.
}

Received: January 3, 2022

doi:10.11114/aef.v9i1.5480
Accepted: February 3, $2022 \quad$ Available online: February 8, 2022

URL: https://doi.org/10.11114/aef.v9i1.5480

\begin{abstract}
This article aims to explain the performance of the banking system in the Central African Economic and Monetary Community (CEMAC) during a crisis period by exploring the average value of the bank profitability indicator. A comparative reading of this indicator between 1986 and 2020 shows that profitability during a crisis period is higher than during the normal period. Using an analysis of the model of banking performance with the method of generalized moments (GMM), the results show that the contradiction relating to the banking performance is explained by: 1)- the strong presence of the State in the capital of commercial banks in the CMEAC zone during the crisis; 2)- the decline in liquidity characteristic of crisis periods also explains this performance of the CEMAC banking sector. It is recommended that the monetary authorities ensure that their decisions are strictly applied by commercial banks in normal times as well as in times of crisis
\end{abstract}

Codes JEL: G21, G01, L25

Keywords: banks, performance, financial crisis

\section{Introduction}

The performance of the banking system in the context of a crisis must be considered in the theory of the banking firm. This is a crucial question insofar as Vasseur (1978) asserts that one cannot deal with the bank while ignoring the economic, social and even political context in which it operates. In the context of crisis, the functions of the banking system are disrupted. For Reinhart and Rogo (2009), crises harbor contradictions. They manifest themselves in a massive and prolonged collapse of real estate and financial asset prices, employment and GDP; they also weaken the fiscal positions of states. But they also correspond to credit booms.

The CEMAC banking system has experienced crises, particularly the severe crisis of the 1980s which led to the collapse of the system and to reforms in the 1990s. Despite the existence of a regulatory arsenal in terms of banks' balance sheets, their solvency, and compliance with bond reserves, there is no guarantee that crises will not recur. This raises the question of the performance of banks. The stakes are their durability, their capacity for resilience and even their survival.

Most studies of the CEMAC banking sector have not addressed the issue of its performance in times of crisis. Studies on European and American areas point to a decline in performance during crises. This study differs from the previous ones because of the specificity of the CEMAC banking system, which is characterized by low levels of bank penetration, poor integration with international financial markets and limited financial innovation.

According to Ningaye, Madaha, Mathilde and Nembot (2014), the banking crisis of the 1980s was the most severe. It was manifested by severe cash flow stress, accumulation of deficit management balances, large sunk funds, and near-negative bank profitability ratio and close to zero in all states. It led to the failure of 9 out of 40 banks. The economic crisis that began in June 2014 is affecting all sectors and seems to last due to the decline in prices of raw materials exported by the countries of the zone.

The objective of this research is to explain the performance of the CEMAC banking system during crises. The hypothesis supported is that disruptions related to financial crises aggravate risks and compromise bank operations and 
performance (Bany, 2015). Banks are expected to perform poorly during crises. The analyses are based on the theory of the banking firm. Indeed, in times of crisis, the credit channel as one of the sources contributing to the profit of the business can no longer function normally. Moreover, in light of performance theories, banks, like all firms, seek to maximize their profit, develop strategies to increase their market share and ensure that their margins are growing. The literature review shows that crises reduce the profitability of banks, lead to illiquidity and in some cases to bankruptcy.

The outline of this paper is as follows. The first point presents the CEMAC banking system as the object of study. The second point is devoted to the literature review, the third to the methodology and the fourth to the results and interpretations.

\section{The CEMAC Banking System}

Like any modern banking system, the CEMAC banking system has the following functions: "the transfer of resources in space and time, the transformation of rights and obligations, the allocation of risks, the provision of information, the management of adverse incentives and finally the provision of means of payment" (Goux, 2010).

Ultimately, it is a matter of ensuring intermediation between economic agents with financing capacity and those with financing needs, thus going beyond the traditional role assigned to the banking firm, which consists of collecting savings and granting loans. Contrary to the compartmentalization in a single system stricto sensus (capital market system versus debt system), this system is to be inscribed in the financial system of debt administered by the Central Bank, but with a monetary policy resorting to hybrid instruments: credit control, reserve requirements and action on interest rates.

To date, it is composed of about 51 banks, including 9 retail financial institutions, all of which are linked to the Central Bank. Ten years ago (in 2010), this number was 43 . The number of banks has been increasing for decades, relatively reinforcing the densification and banking recognized very low (less than $4 \%$ ).

Banks are the main component, followed by a few financial institutions (especially micro-finance institutions) specializing in credit sales, leasing, factoring, investment and SME financing and savings collection. Insurance structures also play an important role. Stock market structures are embryonic, with two stock exchanges (the Douala Regional Stock Exchange in Cameroon and the Central African Stock Exchange in Libreville).

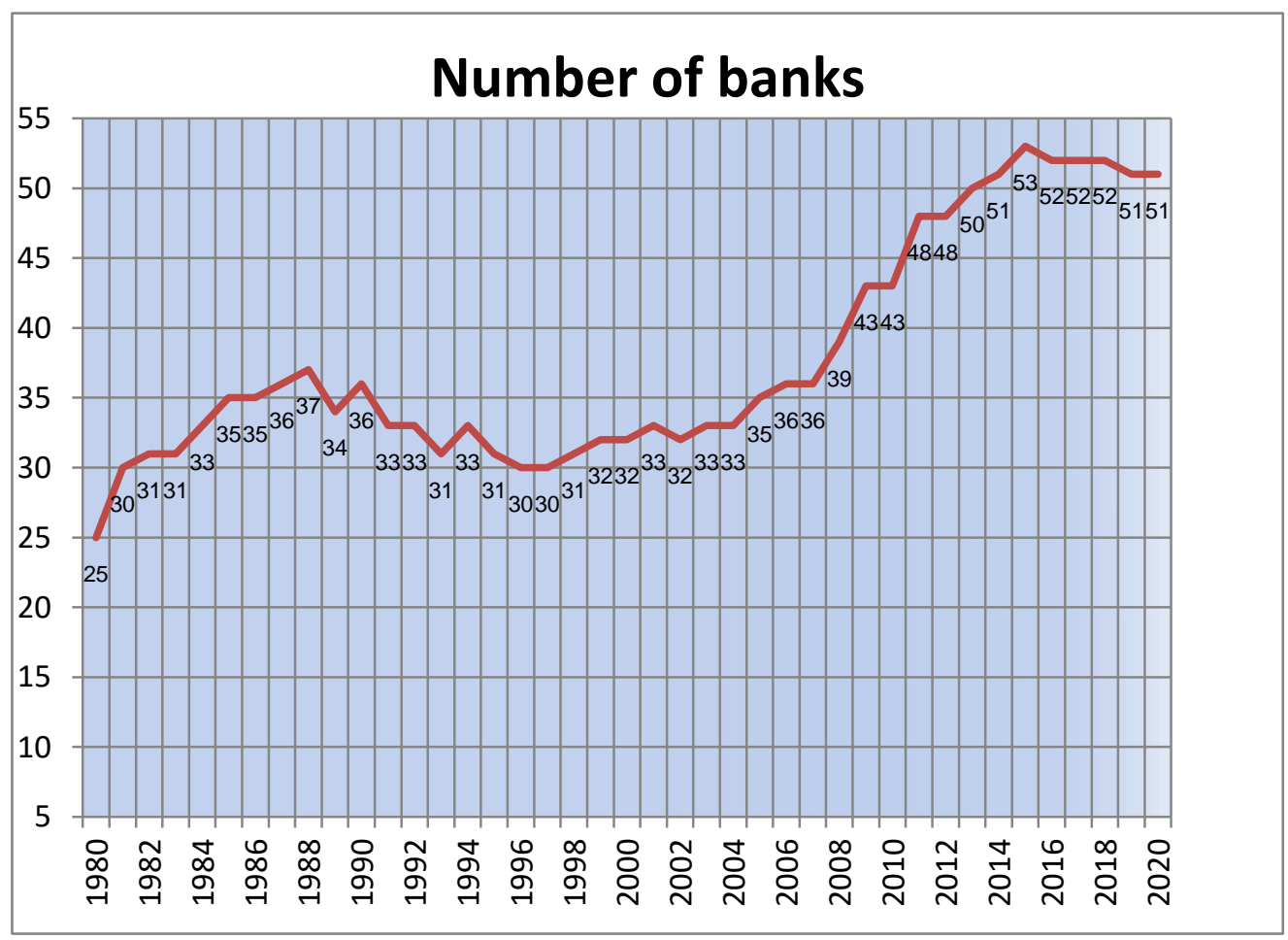

Figure 1. Evolution of the number of banks between 1980 and 2020

Source: Author, based on BEAC data

The number of banking structures is increasing slightly. Three main trends can be observed in Graph 1: a first period of increase in the number of banks (from 1980 to 1988), followed by a period of closure of some banks (from 1989 to 
1999-2000); the third period corresponds to that of a remarkable increase in the number of banking institutions from 2001-2002.

Banks are diversely distributed in the six (6) member states of the community. Cameroon dominates in terms of the number of banks and financial institutions, followed by Congo and Chad.

Banking activity appears to be flourishing, and balance sheets regularly show surpluses: over 617 billion in 2019 and 791 in 2018 . The results in 2010 were also flourishing: 654.50 billion. Over time, these surpluses have contributed to the system's profitability and excess liquidity (Hugon, 2007).

Figure 2 below on credit to the private sector shows that the financing of the economy evolves in a random fashion during the period 1985-2019. This is in contrast to the observation of excess liquidity. The low quality of credit demand, whose files do not meet the banks' criteria, explains this weakness (Hugon, 2007).

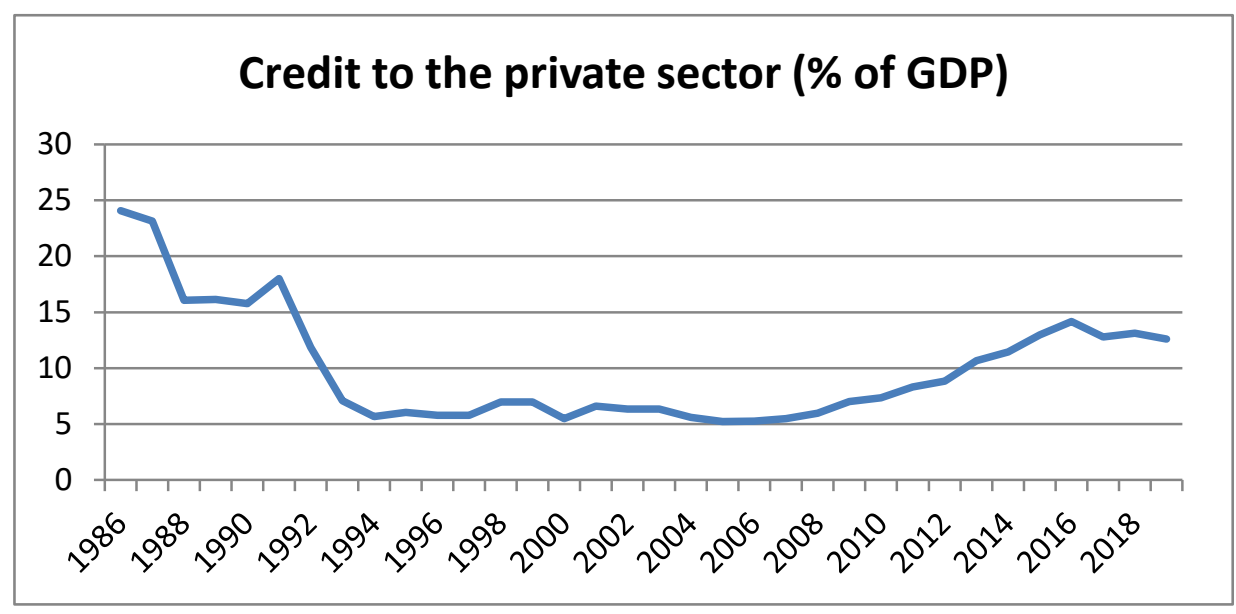

Figure 2. Private sector credit

Source: Author, based on World Development Indicators (2021)

The graph shows a downward trend in the supply of credit between 1985 and 1994, followed by a period of relative decline. The increase in financing for the economy takes off from 2008. Credit to the private sector has not been consistent. It has not exceeded $25 \%$ of GDP, which represents little financing of the economy.

The CEMAC banking system lost credibility following the economic and financial crisis of the mid-1980s and early 1990s, which led to the devaluation of the CFAF. Subsequent financial crises have damaged economies. The performance of a banking system is neither guaranteed nor systematic. They must be sought and maintained.

\section{Review of the Literature}

Financial crises originate, develop and propagate from several explanatory factors. Jedidi and Pentecost (2015) identify four waves of banking crises after the credit boom of the 1970s. The first is the crisis of the early 1980s that particularly hit Latin American and African countries. The second hit OECD countries in the early 1990s. The third hit emerging economies and those in the late 1990s. The fourth began in 2007 in the United States before spreading to Europe and the world. Credit booms are seen as the source of the crises. The duration of the crisis depends on the level of development of the financial system: on average, it is 5 years for advanced economies, 3 years for emerging countries and 2 years for developing economies.

The warning variables considered to herald the crisis are the credit boom and the volatility of interest rates. These are particularly indexed as determinants of banking crises (Eichengreen \& Arteta, 2000; Daniel, 2013). Other determinants include the pro-cyclicality of credit and the importance of non-performing loans, high domestic credit growth, and a large ratio of debt to reserves. Other determinants include poor government credit controls, poor bank management, inadequate monetary policy, unfavorable macroeconomic conditions, and a weak legal and regulatory framework.

The adverse effects of banking crises are reported in almost all empirical studies on the subject. According to Plane and Pujals (2009), the financial crisis jeopardizes the solvency of banks, the depreciation of assets, the loss of market capitalization, the rise in default rates, and the fall in banks' net results. The 2007 financial crisis caused $\$ 2.7$ trillion in U.S. asset write-downs between 2007 and 2010 (International Monetary Fund, 2009). Global market capitalization losses were about $\$ 28$ trillion, European market capitalization losses were about $\$ 9.1$ trillion. 
The literature as a whole tends to suggest that bank profitability is impaired by financial crises. This is because bank credit, the main source of funding, suffers losses due to borrower defaults as well as difficulties in obtaining new funding due to high uncertainty, which reduces banks' willingness to adapt to the crisis. Systemic and illiquidity risks dampen the willingness of financial institutions to lend to other banking structures (Laeven \& Valencia, 2013).

The work of Reinhart and Rogoff (2009) is very representative of this prevailing trend of negative effects of crises on the banking system. According to these authors, banking crises result in a sharp contraction in asset prices, credit supply, and output, as well as a significant increase in the unemployment rate and government debt. The effects on financing are harmful for companies in terms of activity and the lower valuation of their fixed assets. The recessionary process eventually affects banks.

According to Laeven and Valencia (2013), the profitability of financial institutions deteriorates as a result of the crisis. The decline in the supply of credit and asset prices leads to a reduction in the wealth of individuals. The reaction of banks is to reduce the supply of credit and increase their interest rates. This behavior explains the prudence of banks and their demand for credit.

These effects have been put into perspective by Bernanke and Gertler (1995), who believe that central bank interventions in times of crisis can mitigate the negative effects by reviving the banking system through the manipulation of credit and interest rates. If these interventions succeed in reducing the cost of external financing, adverse selection and moral hazard, they will become a powerful financial gas pedal. This would then reduce the likelihood of banks achieving the catastrophic outcomes (Basu \& Bundick, 2012).

Arthus, Betbeze, De Boissieu and Capelle-Blancard (2008) analyzed the 2007 subprime crisis and argue that the effects of this crisis in the United States and Europe were the drying up of bank liquidity, operating losses, and a credit crunch. Banks' earnings are being affected by rising defaults by real estate borrowers, capital losses on securitized loans, and capital losses on tranches. The losses incurred by banks have eroded their capital base and may exacerbate the near-term risk of a contraction in credit supply if regulatory capital ratios begin to become binding. The methodology used is a comparison of banking indicators before and after the crisis.

Dell Ariccia, Detragiache and Rajan. (2008) show that the effects of financial crises depend on the level of financial development. The higher the level of financial development, the more severe the consequences. Moreover, firms that are heavily dependent on external sources of finance suffer more from the effects of the crisis than others. Thus, the growth rate of value added is reduced.

Detragiache, Tressel and Turk-Ariss (2018) show, using descriptive statistics, that the return on equity of banks worldwide declined after the crisis. On average, it went from 3.3\% before the economic boom to $15.7 \%$ during the boom. As a result of the crisis, it fell to $3.1 \%$ and then 3.2\% later. The decline is greatest in Europe (from 16.3\% before the crisis to $2.4 \%$ after the crisis), then in the USA (15.0\% before the crisis, $4.2 \%$ after). In Africa,

Borio and Lowe (2002) specifically analyze credit, stock prices and exchange rates before and after the banking crisis. The sample of 34 countries, including 21 industrialized and 13 emerging countries, covers the period 1960-1999. Before the crisis, credit and exchange rate spreads increase until they peak in the crisis year. After the crisis year, they fall. Stocks rise and fall before the crisis. They rise after the crisis, while credit and exchange rates fall.

Concerning crises in the CEMAC zone, there is no research analyzing the profitability of banks during a crisis in the CEMAC. Studies on other regions show that the crisis leads to a decline in profitability. This situation often justifies the intervention of the Central Bank to rescue the banking sector.

Beyond the differences or contradictions in the results of studies on bank performance, most authors agree on measuring bank performance by return on assets (ROA), return on equity (ROE) or net interest margin (NIM). In a study on the determinants of banking performance in Côte d'Ivoire, Dembélé and Machrafi (2021) evaluate performance using the return on assets (ROA) indicator to the detriment of the return on equity (ROE) and the net interest margin (NIM). Moreover, whether it is the return on assets (ROA) or the return on equity (ROE), the main determinants are of two types: internal and external (Schwaiger \& Liebig, 2008; Dembélé \& Machrafi (2021). Internal determinants include size, capitalization, liquidity, credit quality, efficiency, control, degree of diversification, amount of bank deposits, governance, market share, etc. Externally, bank performance is determined by such things as inflation, GDP growth, tax system, market concentration, stock market, etc.

In a similar study of the banking sector in Cameroon (a CEMAC member country), on a sample of eight (8) banks out of fifteen (15) operating in Cameroon, during the period 2008 to 2018, Mbatchou Ntchabet, Bandela Menyeng and Youmto (2020) estimate performance by classifying profitability indicators by objective: banking activity objective on the one hand and prudential management objective on the other. Return on assets (ROA) and ROE are the most commonly used indicators. They consider the loan ratio as one of the determinants of banking performance. But 
estimation using other determinants shows that bank performance is penalized by size, capital structure, the ratio of equity to total loans and inflation.

\section{The Methodology Used}

\subsection{The Bank Performance Model}

Similar to the work of Dembélé and Machrafi (2021), the methodology is based on the following linear theoretical model:

$$
\text { yit }=x^{\prime}{ }_{i t} \beta+\alpha_{i}(1)
$$

In this equation $y$ represents the explained variable, $x$ the vector of explanatory variables, $\beta$ the coefficients, $\alpha$ the coefficients of the explanatory variables, $i$ the individuals and $t$ the time.

The explained variable is bank performance. It is captured by profitability. Indeed, the theories of performance and profitability are linked insofar as a good performance results from, among other things, the accumulation of positive results conferring profitability on the bank. Whatever the dependence of banks and the risk they incur, the purpose of their activities should be reflected in their profitability. Performance theory attributes to banks an expertise, they must collect information and transform the deposits received from agents into liquidity that they grant to agents who need it. They must manage their assets with the greatest dexterity and face costs (research, project evaluation, monitoring and control) that they must minimize. Insofar as performance uses the criteria of efficiency, effectiveness, profitability and productivity, it can be assimilated to these criteria. Hence, the use of profitability as an indicator of banking performance. Several financial and accounting measures are mobilized and integrated into its evaluation: calculation of return on investment, return on capital, etc.

The literature shows that banking performance depends on the determinants. We retain, depending on the availability of data, the following determinants: credit, capitalization, liquidity, GDP growth and inflation. The credit variable has been retained in order to take into account the importance of the interest rate in triggering crises. It represents the variable of interest in this study in explaining bank profitability. Crisis periods are characterized by high credit and interest rates. However, the interest rate as a cost of credit is closely related to the latter.

Thus, the model to be estimated is as follows:

$$
\text { txroe }_{\text {it }}=\alpha_{\mathrm{i}}+\beta\left(\text { credit }_{\mathrm{it}}+\mathrm{kptl}_{\mathrm{it}}+\operatorname{liquid}_{\mathrm{it}}+\text { growth }_{\mathrm{it}}+\text { inflat }_{\mathrm{it}}\right)+\varepsilon_{\mathrm{it}}
$$

In this equation, TXROE represents the rate of return, CREDIT represents credit, KPTL represents capital, LIQUID represents liquidity, GROWTH represents GDP growth, and INFLAT represents inflation and $\varepsilon$ represents randomness.

\subsection{Description and Source of Variables}

The different variables are presented as follows:

- Txroe: the rate of return on equity or Return On Equity (ROE) is the ratio of net income to equity.

- Credit: This is the total domestic credit granted by the financial sector. It includes all credit to the various sectors on a gross basis, except credit to central government, which is net. The variable is expressed as a percentage of GDP. It has a positive effect on banking performance.

- Kptl: This is the ratio of the bank's capital and reserves to total assets. Capital and reserves include funds contributed by owners, retained earnings, general and special reserves, provisions and valuation adjustments. This ratio is ambiguous, as its sign on bank profitability can be positive or negative. Indeed, a high ratio reduces profitability. But it can be contradictory. It is expressed as a percentage and the expected sign is positive.

- Liquid: This is the ratio of total loans to total assets. The higher this ratio, the less liquid the bank is. It shows the overall capital adequacy and financial strength of a bank. A lack of liquidity may force a bank to borrow at punishing rates in the interbank market or from the central bank. The expected sign is negative.

- Growth: This variable represents economic growth which is measured by the growth rate of GDP. It affects bank performance by influencing factors that indirectly affect the demand and supply of loans and deposits. We expect a positive relationship between economic growth and bank performance.

- Inflat: this is the annual inflation rate based on the consumer price index, which estimates the increase in the consumer price index for all goods and services as a percentage. If a bank's revenues are growing faster than its costs, inflation should have a positive effect on profitability. Hence, the expected positive sign of this variable.

The data for most of the variables are taken from the World Bank database (World Development Indicators 2021). These include capitalization, liquidity, credit, GDP growth and inflation. 
Data for the return on equity (ROE) indicator and the interbank interest rate are taken from BEAC reports, while data for the lending rate are taken from the World Bank database.

The study period is from 1986 to 2020. The choice of this period is justified in relation to our problem of bank performance in times of crisis. All historical evidence points to the late 1980s and early 1990s as the period of collapse of the CEMAC banking system. From the reforms after this period until the 2014-2015 oil shock, the CEMAC banking system is characterized by excess liquidity.

The difficulty of obtaining data on a single basis forced us to use several data sources. In addition, missing values were filled in using the moving average technique.

The population studied is the panel of six (6) CEMAC member countries.

\subsection{Estimation Technique for the Banking Performance Model in the CEMAC Zone}

The estimation technique is the generalized method of moments, chosen according to the results of the stationarity tests. The Generalized Method of Moments (GMM) in a dynamic panel takes into account the individual (and temporal) specific effects and the correction of the endogeneity bias of the variables. Fixed effects or country heterogeneity factors, taking into account all factors that are constant over time and that have an impact on the explained variable.

More specifically, we used the Generalized Moments in Difference estimator of Arellano and Bond (1991). The validity depends on the error terms not being auto-correlated, providing orthogonality conditions that are linear. The Sargan and Hansen tests allow us to verify the global validity of the instruments.

Regarding the period of banking crises in the CEMAC, the Chow (1960) test is performed on the interbank interest rate series between 1986 and 2020. The year 1999 is chosen as the crisis year. From this year on, the study period 1986-2020 is subdivided into two subsamples in order to analyze the trends in the rate of return between the two subsamples.

\section{Results and Interpretations}

\subsection{The Results Obtained}

The descriptive statistics (Table 1) reveal a total of 210 observations over 35 years for the 6 individuals making up the panel of CEMAC member states. It can be seen that, between 1986 and 2020, the average rate of return (TXROE) was $30.46 \%$. Its values have fluctuated in the range of $-7.5 \%$ to $174.99 \%$. The standard deviation was $33.00 \%$, indicating that the values in this series are scattered around the mean.

Table 1. Descriptive statistics

\begin{tabular}{|c|c|c|c|c|c|c|}
\hline Variables & & Mean & Std. Dev. & Min & Max & \multirow{2}{*}{$\begin{array}{l}\text { Observations } \\
\mathrm{N}=210\end{array}$} \\
\hline txroe & overall & 30.46367 & 33.00837 & -7.5 & 174.99 & \\
\hline & between & & 20.23383 & 12.094 & 68.01 & \multirow{2}{*}{$\begin{array}{lr}\mathrm{n}= & 6 \\
\mathrm{~T}= & 35\end{array}$} \\
\hline & within & & 27.32667 & -35.04633 & 137.4437 & \\
\hline credit & overall & 15.83858 & 13.30452 & -23.19922 & 68.66991 & $\mathrm{~N}=210$ \\
\hline & between & & 2.649628 & 12.44473 & 19.46928 & \multirow{2}{*}{$\begin{array}{l}\mathrm{n}= \\
\mathrm{T}=\end{array}$} \\
\hline & within & & 13.08174 & -21.55042 & 70.31872 & \\
\hline kptl & overall & 12.02225 & 4.078926 & 6.408675 & 23.6775 & $\mathrm{~N}=210$ \\
\hline & between & & 4.166341 & 7.21519 & 19.42264 & \multirow{2}{*}{$\begin{array}{l}n= \\
T=\end{array}$} \\
\hline & within & & 1.450204 & 9.27454 & 17.99475 & \\
\hline liquid & overall & 27.29869 & 22.31284 & 1.638384 & 145.5289 & $\mathrm{~N}=210$ \\
\hline & between & & 15.73361 & 7.825695 & 53.47105 & \multirow{2}{*}{$\begin{array}{l}\mathrm{n}= \\
\mathrm{T}=\end{array}$} \\
\hline & within & & 17.04661 & -7.256653 & 119.3565 & \\
\hline growth & overall & 4.480477 & 14.08801 & -36.69995 & 149.973 & $\mathrm{~N}=210$ \\
\hline & between & & 5.001239 & 1.089132 & 14.48395 & \multirow{2}{*}{$\begin{array}{l}\mathrm{n}= \\
\mathrm{T}=\end{array}$} \\
\hline & within & & 13.32399 & -33.30861 & 139.9695 & \\
\hline inflat & overall & 4.411202 & 9.074537 & -17.64042 & 42.43967 & $\mathrm{~N}=210$ \\
\hline & between & & 2.198958 & 2.327031 & 8.653545 & $\mathrm{n}=$ \\
\hline & within & & 8.84864 & -17.20471 & 42.7692 & $\mathrm{~T}=$ \\
\hline
\end{tabular}

Source: Author, using Stata 14 software

As for the capitalization variable (KPTL), it varies between $6.40 \%$ and $23.67 \%$ with a standard deviation of $4.07 \%$. This means that there is little dispersion of the KPTL variable around the mean value. 
The variable of the banking sector credit (CREDIT) fluctuates between $-23.19 \%$ and $68.66 \%$ and that its dispersion around the mean is low, i.e. a standard deviation close to 0 .

Regarding correlation (Table 2), the rate of return (TXROE) is highly correlated with capitalization and credit (CREDIT). But, credit varies negatively with profitability.

Tableau 2. la corrélation

\begin{tabular}{|l|l|l|l|l|l|l|}
\hline & txroe & kptl & liquid & credit & growth & inflat \\
\hline txroe & 1.0000 & & & & & \\
\hline kptl & $-0.1821^{*}$ & 1.0000 & & & & \\
\hline liquid & -0.1033 & $-0.3539^{*}$ & 1.0000 & & & \\
\hline credit & $0.1874^{*}$ & $0.1617^{*}$ & $-0.5175^{*}$ & 1.0000 & & \\
\hline growth & 0.0534 & -0.0675 & $0.1551^{*}$ & $-0.1935^{*}$ & 1.0000 & \\
\hline inflat & -0.0597 & $0.1688^{*}$ & -0.0197 & 0.0168 & 0.0748 & 1.0000 \\
\hline
\end{tabular}

Source: Author, using Stata 14 software

The results of the stationarity tests (Table 3) show that none of the variables is stationary in second difference, and that the variables TXROE, GROWTH and INFLAT are stationary in level and the other variables (KPTL, LIQUID and CREDIT) are stationary in first difference.

Table 3. Stationarity

\begin{tabular}{|c|c|c|c|c|c|c|}
\hline \multirow[t]{4}{*}{ Variables } & \multirow[t]{4}{*}{ Models } & \multirow{2}{*}{\multicolumn{2}{|c|}{$\begin{array}{l}\text { At level } \\
\text { P-value }\end{array}$}} & \multicolumn{2}{|c|}{$1^{\text {st }}$ differencz } & \multirow[t]{4}{*}{ Decisions } \\
\hline & & & & & & \\
\hline & & Common & Individuel & Common & Individuel & \\
\hline & & LLC & IPS & LLC & IPS & \\
\hline \multirow[t]{3}{*}{ txroe } & constant & 0.0314 & 0.0034 & 0.0000 & 0.0000 & \multirow{3}{*}{$\mathrm{I}(0)$} \\
\hline & constant and a trend & 0.0177 & 0.0035 & 0.0000 & 0.0000 & \\
\hline & no-constant, no-trend & 0.0011 & & 0.0000 & & \\
\hline \multirow[t]{3}{*}{ kptl } & constant & 0.8365 & 0.7830 & 0.0000 & 0.0000 & \multirow{3}{*}{$\mathrm{I}(1)$} \\
\hline & constant and a trend & 0.1906 & 0.6729 & 0.0000 & 0.0000 & \\
\hline & no-constant, no-trend & 0.5722 & & 0.0000 & & \\
\hline \multirow[t]{3}{*}{ liquid } & constant & 0.3786 & 0.4383 & 0.0000 & 0.0000 & \multirow{3}{*}{$\mathrm{I}(1)$} \\
\hline & constant and $a$ trend & 0.7968 & 0.8842 & 0.0000 & 0.0000 & \\
\hline & no-constant, no-trend & 0.0986 & & 0.0000 & & \\
\hline \multirow[t]{3}{*}{ credit } & constant & 0.2776 & 0.3615 & 0.0000 & 0.0000 & \multirow{3}{*}{$\mathrm{I}(0)$} \\
\hline & constant and a trend & 0.2455 & 0.9500 & 0.0000 & 0.0000 & \\
\hline & no-constant, no-trend & 0.1220 & & 0.0000 & & \\
\hline \multirow[t]{3}{*}{ growth } & constant & 0.0000 & 0.0000 & 0.0000 & 0.0000 & \multirow{3}{*}{$\mathrm{I}(0)$} \\
\hline & constant and $a$ trend & 0.0001 & 0.0000 & 0.0000 & 0.0000 & \\
\hline & no-constant, no-trend & 0.0000 & & 0.0000 & & \\
\hline \multirow[t]{3}{*}{ inflat } & constant & 0.0000 & 0.0000 & 0.0000 & 0.0000 & \multirow{3}{*}{$\mathrm{I}(0)$} \\
\hline & constant and a trend & 0.0000 & 0.0000 & 0.0000 & 0.0000 & \\
\hline & no-constant, no-trend & 0.0000 & & 0.0000 & & \\
\hline
\end{tabular}

Source: Author, using Stata 14 software

\subsection{Estimation and Interpretation of the Crisis Period and the Parameters that Explain Bank Performance}

The Chow (1960) test presented in Table 4 for the crisis period is based on the interbank interest rate. According to Eichengreen and Arteta (2000), this rate is a determining factor in the occurrence of crises. Crises can be observed in periods of high interest rate liberation.

Table 4. Results of the Chow test (1960)

Chow Breakpoint Test: 1999

Null Hypothesis: No breaks at specified breakpoints

Varying regressors: All equation variables

Equation Sample: 19862020

F-statistic 


\begin{tabular}{|l|l|l|l|l|}
\hline Log likelihood ratio & 2.884043 & & Prob. Chi-Square(2) & 0.2364 \\
\hline Wald Statistic & 2.662634 & & Prob. Chi-Square(2) & 0.2641 \\
\hline
\end{tabular}

Source: Author, using Stata 14 software

Figure 3 below shows the evolution of interest rates.

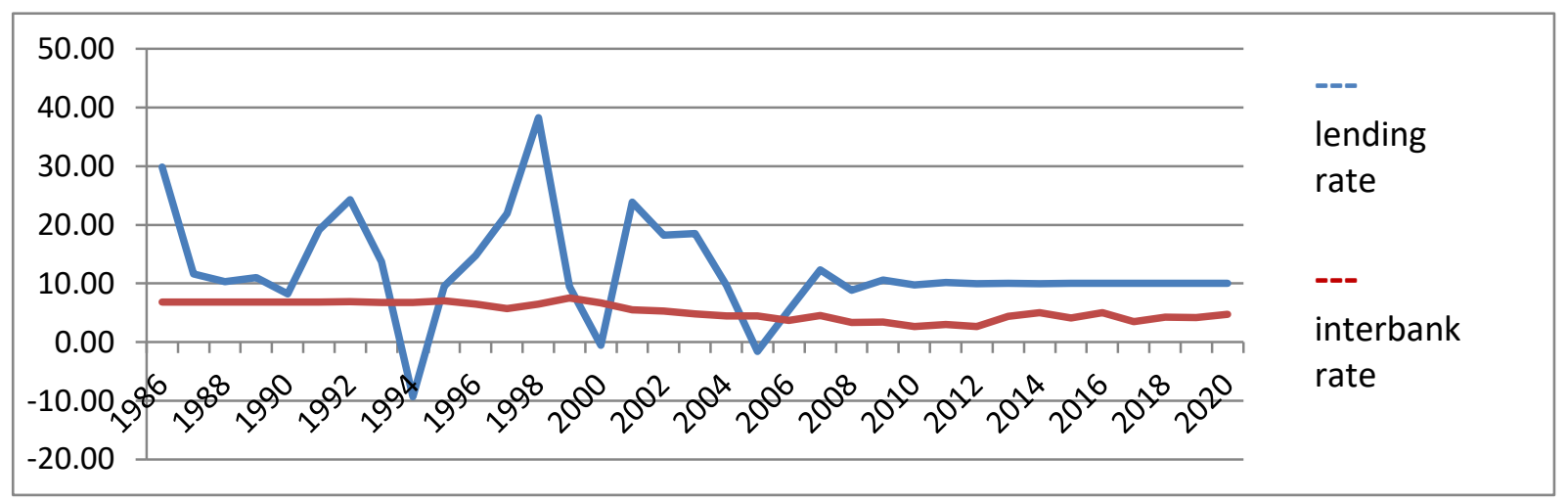

Figure 3. Evolution of interbank and lending interest rate between 1986 and 2020

Source: Author, based on BEAC and World Bank data (World Development Indicators 2021).

Starting in 1999, two sub-periods or sub-samples can be distinguished. The sub-period from 1986 to 1999 , and the one from 2000 to 2020. The two curves vary differently. The lending rates of the banking system fluctuate until they exceed $30 \%$. Interbank rates have remained below $10 \%$ throughout the period. It can also be noted that since 1999 , the interbank rate has not exceeded the $7.5 \%$ ceiling reached in 1999 .

As for profitability, it is represented in a comparative approach according to the periods in the graph below:

Crisis period

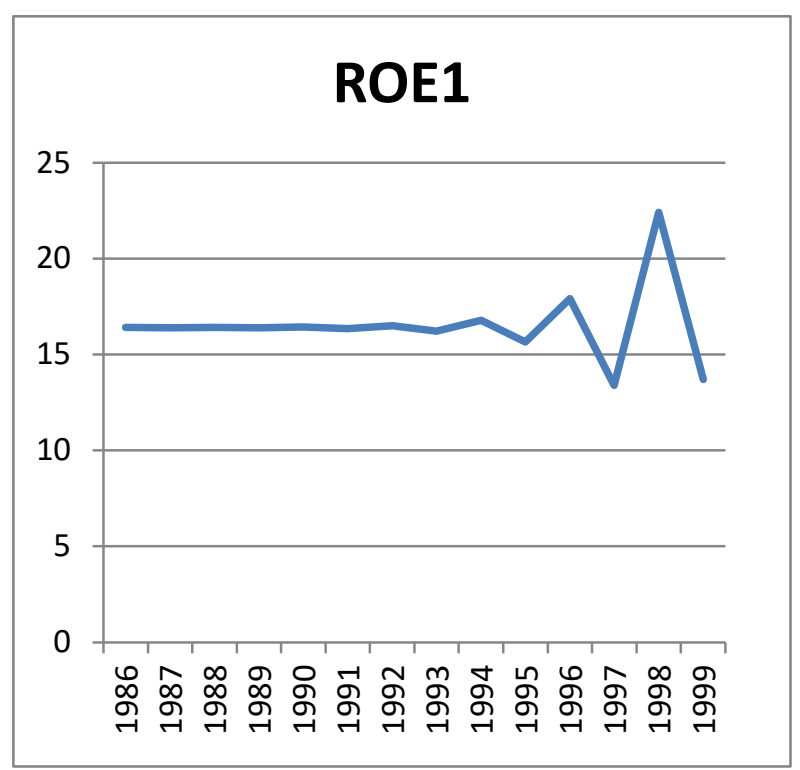

Normal period

\section{ROE2}

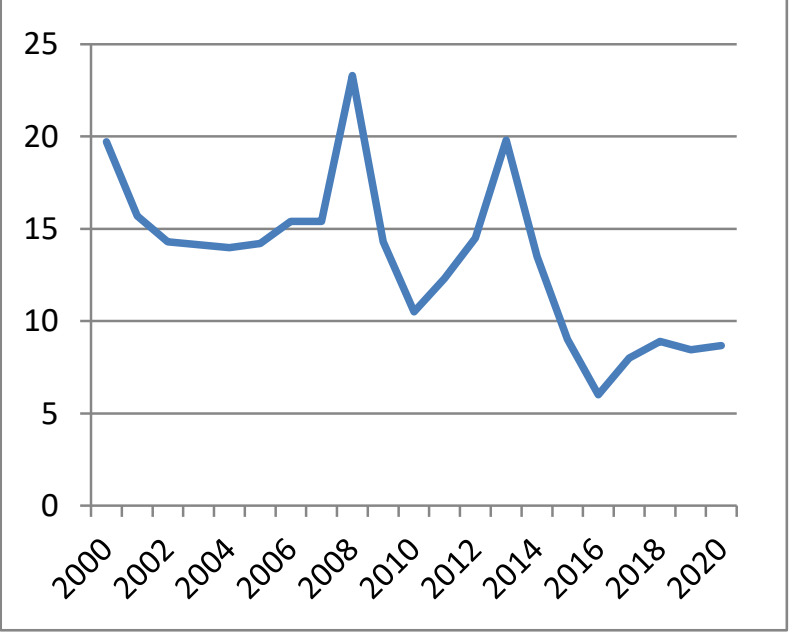

Figure 4. Evolution of bank profitability in crisis and normal periods

Source: our calculations 
The return on equity (ROE) index varies randomly in times of crisis and in normal times. However, the variations are more pronounced in normal periods.

The average of the bank profitability index in crisis periods (ROE1) is 16.3. The maximum value is 22.4 and the minimum value is 13.4 , with a standard deviation around $2 \%$. In normal times, it is $15.5 \%$, oscillating between a minimum of 10.5 and a maximum of $23.3 \%$.

In average values, bank profitability was relatively higher in times of crisis than in normal times. This is a persistent contrast. Indeed, the result remains almost unchanged when we look only at the values of profitability between 1997 and 1999 , which averaged $15.9 \%$. Similarly, the average profitability between 2000 and 2002 is $15.9 \%$. We cannot therefore reject our first result of a high profitability of the CEMAC banking system during the crisis.

According to the graph, the reference year of the crisis (1999) is preceded by a sharp spike in bank profitability, which rises from $13.4 \%$ in 1997 to $22.4 \%$ in 1998 . The drop to $13.7 \%$ in 1999 corresponds to the banking crisis confirmed by the Chow (1960) test performed earlier.

The scenario seems to be repeated in the second sample corresponding to the normal period. Indeed, the profitability peak of $23.3 \%$ in 2008 is followed by a drop to $14.3 \%$ in 2009 and $10.5 \%$ in 2010 . This suggests that the sudden peaks in profitability in the CEMAC banking system occur in a crisis context. The 1998 peak is linked to the financial market crisis in emerging countries, including Russia. The 2008 peak coincides with the global subprime crisis in the United States.

This result is consistent with the finding of Eichengreen and Arteta (2000) that high interest rates coincide with the immediate onset of crises. High interest rates give banking structures high profitability.

Even if the null hypothesis of the Chow (1960) test applied to the years 2008, 2009 and 2010 is accepted, it is clear that the 2008 financial crisis that originated in the United States hit the CEMAC zone with a contagion effect delayed by one or even two years. The CEMAC banking system was more affected two years later (2010) than in 2008. Bank profitability fell, but then rose again starting in 2011.

The second subsample runs from 2000 to 2020 . From this period, we rely on the normal functioning of the banking system. Several economic facts support the normality of the selected period, in contrast to the "troubled times" of the 1980s-1990s. Because of the banking crisis, the monetary authorities implemented reforms that created structures such as the Banking Commission of Central Africa (COBAC), the Group of Actions for Money Laundering (GABAC) and strengthened regulations. This has made it possible to strengthen prudential standards for bank management.

The results of the specification tests (Hausman test table 8) for the choice between the fixed-effects model (table 5) and the random-effects model (table 6) can be found in the Appendix. This led to the choice of the fixed effects model.

The results of the estimation of the panel fixed effects model with the GMM method are shown in Table 7 below:

Table 7. Results of the estimation of banking performance

\begin{tabular}{|l|l|l|l|l|l|l|}
\hline Variables & Coef. & $\begin{array}{l}\text { Robust } \\
\text { Std. Err. }\end{array}$ & $\mathrm{z}$ & $\mathrm{P}>|\mathrm{z}|$ & \multicolumn{2}{l|}{$[95 \%$ Conf. Interval] } \\
\hline txroe L1. & $0,5114229 * * *$ & 0,0694665 & 7,36 & 0.000 & 0,3752711 & 0,6475746 \\
\hline credit & 0,1557467 & 0,1036855 & 1,5 & 0,133 & $-0,0474732$ & 0,3589666 \\
\hline kptl & $-3,256977 * * *$ & 0,4615527 & $-7,06$ & 0.000 & $-4,161604$ & $-2,352351$ \\
\hline liquid & $-0,1515919 * *$ & 0,0761638 & $-1,99$ & 0,047 & $-0,3008702$ & $-0,0023137$ \\
\hline growth & 0,0353735 & 0,035711 & 0,99 & 0,322 & $-0,0346187$ & 0,1053658 \\
\hline inflat & $-0,0713397$ & 0,0879687 & $-0,81$ & 0,417 & $-0,2437552$ & 0,1010757 \\
\hline annees & $-0,4971013$ & 0,2333469 & $-2,13$ & 0,033 & $-0,9544529$ & $-0,0397497$ \\
\hline
\end{tabular}

Arellano-Bond test for AR(1) in first difference : $\mathrm{z}=-1.68 \quad \operatorname{Pr}>\mathrm{z}=0.092$

Arellano-Bond test for AR(2) in first difference : $\mathrm{z}=1.57 \quad \operatorname{Pr}>\mathrm{z}=0.116$

Source: Author, using Stata 14 software. ${ }^{* * *}, * *$, significant at the $1 \%$ and $5 \%$ levels respectively

The probabilities associated with the Arellano-Bond test, namely AR (2) is 0.115 is greater than the $5 \%$ threshold, and that AR (1) is 0.092 less than $1 \%$. This means that the model is valid and explained by several variables.

The coefficient associated with the variable CREDIT is positive as assumed but statistically insignificant. This means that the credit granted by financial institutions, although positively correlated with bank profitability, does not explain bank profitability in the CEMAC zone. 
The coefficient associated with the KPTL variable is as expected negative and statistically significant at the $1 \%$ level. Similarly, the coefficient on the LIQUID variable is negative and statistically significant at the 5\% level. Both variables negatively explain performance in the CEMAC zone. This means that an increase in either of these variables leads to a decrease in bank performance.

The other variables are not significant. Only the variable TXROE lagged by one period is positive and significant at the $1 \%$ level. This means that the current year's profitability is positively influenced by the previous year's profitability.

However, the results did not allow us to verify our hypothesis that the credits granted by the banks positively influence their profitability, neither before the banking crisis of 1999 nor after.

The significance and sign of the KPTL variable can be explained by the arguments of Mbatchou Ntchabet, Bandela Menyeng and Youmto (2020) that the bank with majority government ownership is more likely to negatively affect the bank's performance and that the government rarely diversifies its capital.

It is interesting to try to understand why profitability on average during the crisis is higher than during the normal period. The literature shows that crisis periods are characterized by high cash flow pressures, deficit balances, and bad and doubtful debts. Bank failures are more plausible during crisis periods than during normal periods.

Banking performance during crisis periods in the CEMAC zone can be explained by the predominance of the government in the capital of most banks from the 1980s until the early 2000s. The banking crisis of the 1980s and 1990s contributed to the deterioration of capital without affecting profitability.

We can add to this the decrease in liquidity due to the crisis. Banks are becoming more vigilant because of the crisis, which leads to lower profitability and capitalization, among other things. One of the main characteristics of the CEMAC banking crisis was the decline in liquidity, whereas after the crisis, particularly from the year, CEMAC liquidity increased.

The banks avoided falling into the management errors of the years that led to the bankruptcy of the 1980s. They are developing reflexes of timidity when their environment becomes uncertain and are activating the mechanisms of prudential standards to ensure that they do not go in the wrong direction.

The CEMAC zone therefore appears to be an atypical zone, with a banking system characterized by declining liquidity and capitalization between 1986 and 1999 (the period of the crisis), making the system perform well. Paradoxically, the period from 2000 to 2020 , characterized by high liquidity and capitalization dominated by the private sector, is comparatively less efficient.

\section{Conclusion}

The objective of this article was to explain the performance of the banking system in the Central African Economic and Monetary Community (CEMAC) during a crisis period. The average of the bank profitability indicator between 1986 and 2020 shows that profitability in the crisis period (1986-1999) is higher than in the normal period (2000-2020). These results are inconsistent with most of the work presented in the literature review.

However, these results are explained by the preponderance of the state in the capital of most banks in the zone. Also, the crisis itself caused the scarcity of liquidity to contribute to this performance, as the crisis made banks cautious of the little liquidity they had in order to avoid the setbacks experienced in previous years.

The results of this article constitute an important empirical contribution. They show that the determinants of performance are not unanimous among the authors. If statistical data were available, this study would benefit from being enriched with other variables such as credit risk, the banking environment, compliance with regulations, etc.

Monetary authorities should ensure that their decisions are strictly enforced by commercial banks in times of crisis as in normal times. The capital structure of banks should be in accordance with the regulations in force in the CEMAC in order to avoid the adverse effects of capitalization on banking performance.

\section{References}

Arellano, M., \& Bond, S. (1991). Some tests of specification for panel data: Monte Carlo evidence and an application to employment Equations. Review of Economic Studies, 58, 277-297. https://doi.org/10.2307/2297968

Arthus P., Betbeze J. P., De Boissieu, C., \& Capelle-Blancard, G. (2008). La crise des Subprimes, Conseil d'Analyse Économique, La Documentation française, p. 12.

Bany, R. F. D. (2015). Les activités de Hors Bilan améliorent-elles l'efficience bancaire ? Une vérification empirique dans le cas de la CEMAC. Journal of Economics and Development Studies, 3(3), 19-35.

Basu, S., \& Bundick, B. (2012). Uncertainty Shocks in a Model of Effective Demand. NBER Working Papers No 18420. https://doi.org/10.3386/w18420 
Bernanke, B. S., \& Gertler, M. (1995). Inside the Black Box: The Credit Channel of Monetary Policy Transmission. Journal of Economic Perspectives, 9(4), 27-48. https://doi.org/10.1257/jep.9.4.27

Borio, C., \& Lowe, P. (2002). Évaluation du risque de crise bancaire, Rapport trimestriel BRI.

Chow, G. (1960). Tests of Equality Between Sets of Coefficients in Two Linear Regressions. Econometrica, 28(3), 591-605. https://doi.org/10.2307/1910133

Daniel, L. (2013). Les taux d'intérêt: origines et vecteurs de la crise, Marché et organisations, 19, $165-188$. https://doi.org/10.3917/maorg.019.0165

Dembélé, B. S., \& Machrafi, M. (2021). Les déterminants de la performance bancaire : une étude empirique des six grandes banques ivoiriennes. Revue du Contrôle de la Comptabilité et de l'Audit, 5(1), 309-334.

Detragiache, E., \& Tressel, T., \& Turk-Ariss, R. (2018). Where Have All the Profits Gone? European Bank Profitability over the Financial Cycle, INTERNATIONAL MONETARY FUND Working Paper 18/99. https://doi.org/10.5089/9781484354544.001

Eichengreen, B., \& Arteta, C. (2000). Banking Crises in Emerging Markets: Presumptions and Evidence, $\mathrm{N}^{\circ} \mathrm{C} 00-115$, Center for International and Development Economics Research, Working Papers from University of California at Berkeley.

Goux, de Jean-François. Macroéconomie monétaire et financière, Paris, Economica.

Hugon, P. (2007). Rentabilité du secteur bancaire et défaillances du financement du développement: le cas de la CEMAC. Revue Tiers Monde, 4(192), 771-788. https://doi.org/10.3917/rtm.192.0771

International Monetary Fund. (2009). La crise financière internationale et la récession mondiale : impact sur la région de la CEMAC et considérations stratégiques, SPN/09/20.

Jedidi, O., \& Pentecôte, J. B. (2015). Prédire les crises bancaires: un système d'alerte robuste. Revue française d'économie, 3(XXX), 189-225. https://doi.org/10.3917/rfe.153.0189

Laeven, L., \& Valencia, F. (2013). Systemic Banking Crises Database. INTERNATIONAL MONETARY FUND Economic Review, 61(2), 225-270. https://doi.org/10.1057/imfer.2013.12

Mbatchou, N. A. Y., Bandela, M. C., \& Youmto, E. (2015). Les déterminants de la performance financière des banques commerciales au Cameroun : une étude en panel. Revue internationale des sciences de gestion, 3(3).

Ningaye, P., Madaha, Y. M., \& Nembot, N. L. (2014). Competition and Banking Efficiency in the CEMAC Zone. International Journal of Economics and Finance, 6(6). https://doi.org/10.5539/ijef.v6n6p127

Plane, M., \& Pujals, G. (2009). Les banques dans la crise. Revue de l'OFCE, 110(3), 179-219. https://doi.org/10.3917/reof.110.0179

Reinhart, C. M., \& Rogoff, K. S. (2009). The Aftermath of Financial Crises. American Economic Review, 99, $466-472$. https://doi.org/10.1257/aer.99.2.466

Schwaiger, M. S., \& Liebig, D. (2008). Determinants of bank interest margins in Central and Eastern Europe. Financial Stability Report, 14, 68-87 (Österreichische Nationalbank).

Vasseur, M. (1976). Droit et économie bancaires. Ed. Les cours de droit, p. 94.

\section{Appendices}

Table 5. Results of the fixed effects model

\begin{tabular}{|c|c|c|c|c|c|c|}
\hline txroe & Coef. & Std. Err. & $\mathrm{T}$ & $\mathrm{P}>|\mathrm{t}|$ & \multicolumn{2}{|c|}{ [95\% Conf. } \\
\hline kptl & $-8,739781$ & 1,116034 & $-7,83$ & 0 & $-10,94055$ & $-6,53901$ \\
\hline liquid & $-0,609806$ & 0,1166477 & $-5,23$ & 0 & $-0,839831$ & $-0,379782$ \\
\hline credit & 0,2624375 & 0,1538271 & 1,71 & 0,09 & $-0,040903$ & 0,5657777 \\
\hline growth & 0,072078 & 0,12233 & 0,59 & 0,556 & $-0,169152$ & 0,3133075 \\
\hline inflat & $-0,266807$ & 0,1778798 & $-1,5$ & 0,135 & $-0,617578$ & 0,0839647 \\
\hline cons & 148,8798 & 14,61735 & 10,19 & 0 & 120,055 & 177,7046 \\
\hline
\end{tabular}

Source: Author, using Stata 14 software 
Table 6. Results of the random effects model

\begin{tabular}{|l|l|l|l|l|l|l|}
\hline txroe & Coef. & Std. Err. & $\mathrm{Z}$ & $\mathrm{P}>|\mathrm{z}|$ & \multicolumn{2}{c|}{$[95 \%$ Conf. } \\
\hline kptl & -1.927459 & .5851151 & -3.29 & 0.001 & -3.074263 & -.7806541 \\
\hline liquid & -.1539256 & .1217134 & -1.26 & 0.206 & -.3924794 & .0846283 \\
\hline credit & .4727266 & .1948269 & 2.43 & 0.015 & .090873 & .8545803 \\
\hline growth & .2172904 & .1598588 & 1.36 & 0.174 & -.0960271 & .5306079 \\
\hline inflat & -.1152776 & .2467154 & -0.47 & 0.640 & -.5988309 & .3682756 \\
\hline _cons & 49.88565 & 10.01502 & 4.98 & 0.000 & 30.25657 & 69.51472 \\
\hline \\
corr(u_i, X) Prob > chi2 $=0.0 .0006$ \\
\hline
\end{tabular}

Source: Author, using Stata 14 software

Table 8. Results of the Hausman test

\begin{tabular}{|c|c|c|c|c|}
\hline \multicolumn{5}{|c|}{---- Coefficients ---- } \\
\hline & $\begin{array}{l}\text { (b) } \\
\text { fe }\end{array}$ & $\begin{array}{l}\text { (B) } \\
\text { re }\end{array}$ & $\begin{array}{l}\text { (b-B) } \\
\text { Difference }\end{array}$ & $\begin{array}{l}\text { sqrt(diag(V_b-V_B })) \\
\text { S.E. }\end{array}$ \\
\hline kptl & -8.739781 & -1.927459 & -6.812323 & .9503541 \\
\hline liquid & -.6098063 & -.1539256 & -.4558808 & . \\
\hline credit & .2624375 & .4727266 & -.2102891 & . \\
\hline growth & .072078 & .2172904 & -.1452124 & . \\
\hline inflat & -.2668066 & -.1152776 & -.151529 & . \\
\hline \multicolumn{5}{|c|}{$\operatorname{chi} 2(5)=(b-B)^{\prime}\left[\left(V_{-} b-V_{-} B\right)^{\wedge}(-1)\right](b-B)$} \\
\hline \multicolumn{5}{|c|}{$\begin{array}{l}\text { Prob }>\text { chi2 }=\quad 0.0000 \\
\left(V_{-} b-V_{-} B \text { is not positive definite }\right)\end{array}$} \\
\hline
\end{tabular}

Source: Author, using Stata 14 software

\section{Copyrights}

Copyright for this article is retained by the author(s), with first publication rights granted to the journal.

This is an open-access article distributed under the terms and conditions of the Creative Commons Attribution license which permits unrestricted use, distribution, and reproduction in any medium, provided the original work is properly cited. 